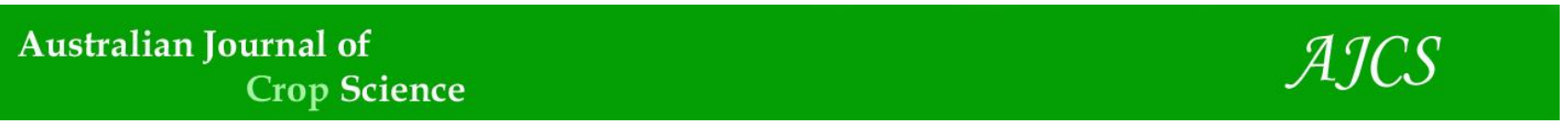

AJCS 14(08):1302-1309 (2020)

ISSN:1835-2707

doi: 10.21475/ajcs.20.14.08.p2586

\title{
Decontamination methods of tanks to spray 2,4-D and dicamba and the effects of these herbicides on citrus and vegetable species
}

\author{
Gustavo Dutra Roesler ${ }^{1}$, Luana Carolina Gomes Jonck ${ }^{1}$, Rafael Pires Silva1, Ana Victoria Jeronimo ${ }^{1}$, \\ Andreia Cristina Silva Hirata ${ }^{2}$, Patrícia Andrea Monquero ${ }^{1}$ * \\ ${ }^{1}$ Department of Natural Resources and Environmental Protection, São Carlos University, Araras, São \\ Paulo State, Brazil \\ ${ }^{2}$ APTA/Polo da Alta Sorocabana, Presidente Prudente, São Paulo State, Brazil
}

*Corresponding author: pamonque@ufscar.br

Abstract

In agriculture, the development of plants resistant to 2,4-D and dicamba tends to result in increased use of these herbicides in agricultural areas and consequently increases the risk in susceptible species. The aims of the present study are to assess the effects of 2,4-D and dicamba on citrus (Citrus sinensis var. Pêra Rio), lettuce (Lactuca sativa var. Stella) and tomato (Lycopersicum esculentum var. Santa Clara) and determine the best method for spray tank decontamination after applying such herbicides. All the experiments followed a completely randomized design with five replications. To study the effects of 2,4-D and dicamba on sensitive plants, experiments were performed on the following cultivated species: citrus, lettuce and tomato. Each species was subjected to 2,4-D (D, $670 \mathrm{~g}_{\text {a.i. }} \mathrm{ha}^{-1}$ ) and dicamba (D, $560 \mathrm{~g}$ a.i. ha ${ }^{-1}$ ) applied at doses of $0 \mathrm{D}, 1 \mathrm{D}, 0.5 \mathrm{D}, 0.12 \mathrm{D}, 0.03 \mathrm{D}, 0.007 \mathrm{D}$ and $0.001 \mathrm{D}$ (of commercial doses (Ds)). In another experiment, the following methods were adopted to clean tanks used to spray 2,4-D and dicamba at commercial doses: wash with water $(1 x)$, water $(2 x)$, water $(3 x)$, water $+96 \%$ alcohol $(1: 1)$, water + detergent $(2.5 \%)$ or no washing. The tanks were filled with water after treatment. The young tomato plants were used as bioindicators. Regarding plant sensitivity, citrus plants exhibited low potential for suffering losses due to 2,4-D and dicamba drift. The plants tolerated a dose of $0.12 \mathrm{D}$ for both herbicides. Lettuce and tomato were extremely sensitive to 2,4-D and dicamba. Lettuce tolerated 2,4-D at a dose of $0.007 \mathrm{D}$ but showed phytotoxicity symptoms; the tolerated dicamba dose was $0.03 \mathrm{D}$. Only the $0.03 \mathrm{D}$ dose of 2,4-D was tolerated by tomato. Although the tomato plants presented phytotoxicity symptoms, the tolerated dicamba dose was $0.007 \mathrm{D}$. For the tank cleaning experiment, the spray tank cleaning by thoroughly washing in water (2x) was the most appropriate method to clean tanks used to spray 2,4-D. Washing with water ( $2 x$, at a minimum), water + alcohol (1:1) or water + detergent was equally effective to clean tanks filled with dicamba. Therefore, the study shows that the application of 2,4-D and dicamba in areas close to young Citrus sinensis plants should be avoided given that vegetable species, such as lettuce and tomato, do not tolerate the minimum drift of these herbicides. Double washing with water would be the most economical and effective method of cleaning tanks used to house these herbicides.

Keywords: Phytotoxicity, tomato, lettuce, subdose, hormone-type herbicides.

Abbreviations: D - commercial rate of the herbicide

Introduction

The license to plant soy cultivars resistant to dicamba was approved in Brazil in 2016 (CTNBio, 2016). The availability of cultivars resistant to auxin-mimetic molecules is an important strategy to control eudicotyledonous weeds in soy crops (Spaunhorst and Siefert-Higgins, 2014). Although the technology of dicamba-resistant soy in the U.S.A. provided farmers better control over weeds, it is clear that drift to sites outside the target crop is an issue that should be assessed to maintain the feasibility and efficacy of this technology in the future (Werle et al., 2018).

The liberation of new dicamba and 2,4-D formulations and their use in transgenic agronomic plants will likely result in more applications throughout the year. The negative aspect of using herbicides involves their drift from the target area because it damages susceptible plant species. Therefore, interest in the herbicide drift issues has been increasing (Mueller, 2015).

Dicamba is a postemergence hormone auxin-mimetic herbicide (Group O, according to the Herbicide Resistance Action Committee (HRAC) of systemic action and belongs to the benzoic-acid chemical group. The first effects of these products on sensitive plants include abnormalities in plants, such as epinoplasty and growth inhibition, with intensified green coloring in leaves within 24 hours after application. These phenomena are followed by damage to chloroplast, which causes chlorosis and disrupts integrated membranes of the vascular system. This process can lead to tissue necrosis (Cobb and Reade, 1992; Grossmann, 2000).

With respect to physical-chemical features, dicamba does not bond to particles in the soil and can contaminate underground water (USDA, 1990). This product undergoes 
minimal photodegradation and can undergo some volatilization on the plant surface (Howard, 1989). The lifespan of dicamba in the soil ranges from 4 to 555 days, and the typical dicamba lifespan ranges from 1 to 4 weeks. The lifespan of dicamba under appropriate fast metabolism conditions is less than 2 weeks (Howard, 1989).

Given concerns with dicamba drift from the target, it is worth focusing on the appropriate administration of this new technology for longer periods (Jones et al., 2018). The application of such herbicides is expected to lead to better weed control in soy crops due to the insertion of a new cultivar that is resistant to auxin-mimic herbicide given the possibility to optimize crop management using these technologies. However, the use of herbicides under conditions unfavorable for their application, such as wind speed greater than $5 \mathrm{~km} / \mathrm{h}$ and significantly small drops (< $200 \mu \mathrm{m})$, can cause herbicide drift (Miller, 1993) and consequently affect nontarget plants.

Drift reduces herbicide effectiveness in controlling weeds. This effect is corrected by compensatory-dose increases, which result in unnecessary expenses and environmental contamination (Hemphill and Montgomery, 1981).

Dicamba drift on non-herbicide-resistant crops and/or on plants can cause irreversible issues, such as chlorosis, necrosis and twisting leaf symptoms, in plants sensitive to 2,4-D, dicamba and picloram (Everitt and Kelling 2009; Marple et al., 2007).

The Minnesota Department of Agriculture set a date for dicamba application and forbids its application when the environmental temperature is expected to be greater than $29^{\circ} \mathrm{C}$. These rules aim to reduce herbicide drift cases, which can impair adjacent fields, and mainly concern soy and cotton crops in the U.S.A. (Demillo, 2017).

Studies on herbicide drift have demonstrated that dicamba can drift up to $152 \mathrm{~m}$ from the target application area. Yield loss reduction was noted in non-dicamba-resistant soy crops that were located $42.8 \mathrm{~m}$ away from the target area after a drift episode at the $\mathrm{R} 1$ reproductive stage. The collected data also suggested that the cultivation stage influenced plant sensitivity to herbicide drift episodes (Jones et al., 2018).

Significant dicamba air concentrations were present 0 to 12 hours after its application. The mean temperature (and other weather variables) was correlated to the detection of higher dicamba levels in the air; the greatest levels were recorded on days with the highest temperatures (Muiller et al., 2013). According to Jones et al. (2018), mean and maximum wind speed did not account for dicamba injuries in soybean. Thus, it is assumed that other meteorological variables also play a key role in drift from dicamba application target areas and postexposure growth conditions.

Damage to sensitive plants due to inadequate use of spraying tanks filled with these herbicides is another pressing issue in addition to hormone herbicide drift. Contamination can occur even several months after tank use if it is not properly cleaned given that herbicide waste inside the tank can be re-diluted through subsequent contact with other herbicides, their solvents or spray adjuvants.

Herbicides can accumulate on the bottom of the tank or corrode the spraying system. Therefore, the device should be cleaned immediately after use. However, studies about decontamination methods against these herbicides are scarce.
The aims of the present study were to assess (a) simulated 2,4-D and dicamba drift over citrus, lettuce and tomato and (b) different decontamination methods against 2,4-D and dicamba that have accumulated in spray tanks.

Results and discussion

\section{The effect of 2,4-D and dicamba on susceptible species}

The phytotoxicity rates resulting from 2,4-D application on citrus seedlings is shown in Figure 1. Growing losses due to increased doses of this herbicide and the high phytotoxicity of its commercial dose are noted. Damage increased throughout the evaluation. Herbicide effects increased from the $7^{\text {th }}$ to the $14^{\text {th }}$ days after application (DAA); phytotoxicity values greater than $70 \%$ were noted at 28 DAA. The plants also showed losses when half of the commercial dose was applied. Effective phytotoxicity reduction was observed only at a simulated drift dose of $0.12 \mathrm{D}$. However, drift of lower herbicide rates was tolerated by the plants (Figure 1).

Wells et al. (2019) observed serious injury in pecan (Carya illinoinensis) trees receiving herbicide contact at rates of $1.0 \%$ dicamba or 2,4-D by volume. According the authors, it is possible that a higher concentration of either of these herbicides would lead to increased translocation and higher levels of foliage injury.

In wine grapes, $1 / 30,1 / 100$, and $1 / 300$ of the recommended field rate of 840 and $560 \mathrm{~g}$ a.i. ha ${ }^{-1}$ for 2,4-D and dicamba, respectively, were applied. Greater than $10 \%$ injury symptoms were observed 42 days after treatment in plants treated with 2,4-D at all doses and plants treated with dicamba at the two highest doses (Mohseni-Moghadam et al., 2016).

On the other hand, Adouli et al. (2018) reported that 2,4-D spray on Satsuma mandarin (Citrus unshiu Marc.) cv. Miyagawa fruits for one year under rain-fed farming conditions during the full bloom period are suitable solutions to control alternate bearing and enhance fruit quality.

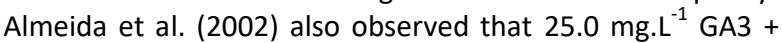
2,4-D applied preharvest to developing orange cv. Hamlin (Citrus sinensis) tree fruit reduced the natural fruit fall percentage compared to the control.

The present study showed increased sensitivity of young citrus plants to the herbicides. This finding suggests that these plants exhibit different toxicity degrees due to plant age, tissue maturity and herbicide dose.

The commercial dose of 2,4-D caused the greatest reduction in shoot dry biomass (Figure 1). The treatment based on applying half of the commercial dose led to biomass increase; specifically, plant recovery values were closer to those recorded for the control from the $28^{\text {th }}$ to the $60^{\text {th }}$ DAA. It is important to highlight that the $1 \mathrm{D}$ treatment led to severe injuries in plants due to high phytotoxicity rates, which can impair and/or make the use of such seedlings unfeasible.

Regarding dicamba (Figure 1), the phytotoxic effect at 28 DAA was approximately $50 \%$ under the highest dose. Treatment with half of the commercial dose also had harming effects on plants, and damage was evident at 14 DAA. The other doses yielded values close to those recorded for the control (dose 0); thus, these data reveal the phytotoxic action of dicamba drift, which is a limiting factor. In contrast to that reported for tobacco plants by Behrens et al. (2007), dicamba fractions up to $17 \mathrm{~g}$ a.i. ha ${ }^{-1}$, which corresponds to approximately 0.03 of the applied 
commercial dose (560 g a.i. ha ${ }^{-1}$ ), caused significant damage. Citrus plants exhibit increased comparative tolerance and were affected only by the $0.5 \mathrm{D}$ herbicide $\left(280 \mathrm{~g}\right.$ a.i. $\left.\mathrm{ha}^{-1}\right)$ at 28 DAA.

Dry biomass was reduced in citrus plants treated with dicamba doses of $0.12 \mathrm{D}$ and greater, and these treatments yielded a stronger negative impact compared with that resulting from the commercial dose.

The significant biomass loss observed in plants subjected to treatment with half of the commercial dose is evidenced by symptoms observed in plants. Accordingly, the action of dicamba in sensitive plants is evidenced by growth abnormalities and inhibition, which can lead to tissue desiccation and necrosis (Grossmann, 2000). Wells et al. (2019) observed foliage deformation, dead foliage, dead limbs and/or branches and arrested nut development in pecan (Carya illinoinensis) trees treated with dicamba and 2,4-D.

Lettuce plants were highly affected by the phytotoxicity of 2,4-D, and this finding highlights the extreme susceptibility of these plants to this herbicide (Figure 2). The symptoms rapidly appeared, and high phytotoxicity values were noted at 7 DAA. Plants died in response to doses up to $0.12 \mathrm{D}$. Drifts from $0.03 \mathrm{D}$ and $0.007 \mathrm{D}$ doses presented highly negative effects at 14 DAA. However, symptom reduction was noted at 28 DAA, and relatively low phytotoxicity rates were observed. Gaspar et al. (2017) assessed various dicamba doses $(0.25 \mathrm{D}, 0.50 \mathrm{D}$ and $1.0 \mathrm{D})$ on lettuce and reported severe injuries (greater than $80 \%$ ) at 15 DAA.

Results have shown the high risk posed by 2,4-D drift on lettuce plants in areas adjacent to those where these herbicides are used. Accordingly, the use of this herbicide must be avoided, mainly in green areas close to urban zones. Fresh biomass data of lettuce plants subjected to different 2,4-D treatments corroborate the phytotoxicity results (Figure 2). A significant reduction in biomass was noted from $0.12 \mathrm{D}$ on, and plant death was observed. The curve revealed that a dose of $0.007 \mathrm{D}$ led to greater lettuce plant recovery, and values were closer to those recorded for the control. These data are similar to results presented by Moro et al. (2012), who reported no significant difference in fresh biomass between lettuce plants treated with $1 / 100$ D 2,4-D and the control.

Studies using sublethal doses of 2,4-D were conducted with different vegetables to determine their effect on plant yield and quality using experiments based on simulated drift. Lettuce (Lactuca sativa L.), onion (Allium cepa L.) and cabbage (Brassica oleracea L. var. Capitata) were the least sensitive to 2,4-D; exposure to $20.8 \mathrm{~g} \mathrm{ha}^{-1}$ 2,4-D did not reduce lettuce yield (Hemphill and Montgomery, 1981). This dose corresponded to $0.03 \mathrm{D}$ in the current study, which resulted in biomass reduction. Factors such as variety, application period, and growth conditions can explain such differences.

Lettuce plants subjected to dicamba drift revealed the high susceptibility of this species (Figure 2). The highest doses of this herbicide (commercial dose and half commercial dose) exhibit the most rapid effect due to the amount of herbicide that accumulated in the tank, and this dose caused plant death. The effects of $0.12 \mathrm{D}$ took a relatively long time but also caused plant death. Phytotoxicity was reduced with doses of $0.03 \mathrm{D}$ and greater, and these doses led to recovery at 28 DAA. However, values were not similar to those recorded for dose zero (0). These data are consistent with experiments conducted by Nascimento et al. (2018) with different vegetable plant species, such as tomato, cucumber, carrot, beet and potato. These vegetable species have shown that dicamba drift at levels up to 0.12 of the commercial dose led to severe injuries in the assessed plants.

Fresh biomass values of lettuce plants upon treatment with $0.03 \mathrm{D}$ or greater dicamba were similar to values observed under dose zero (0). Therefore, plant recovery was observed with the adopted treatments after the evaluation performed at 28 DAA (Figure 2) since biomass was evaluated at 45 DAA. Figure 3 shows 2,4-D phytotoxicity in tomato plants. High phytotoxicity values were noted at $7 \mathrm{DAA}$, and this finding reveals the rapid effect of these herbicides on plants and the high susceptibility of such plants to these herbicides. According to Breeze and West (1987), photosynthesis in tomato plants treated with 2,4-D started to decline within one hour after herbicide exposure.

This phytotoxicity remained high up to dose $0.12 \mathrm{D}$, but the values were reduced to lower rates with doses of 0.03D and greater. However, values similar to the control were observed only with doses less than or equal to $0.007 \mathrm{D}$. These data are consistent with those presented by Santos et al. (2013), who reported potential 2,4-D phytotoxicity in tomato, cucumber and beetroot plants due to higher herbicide doses. In addition, higher doses (187.5, 375 and $750 \mathrm{~g}$ commercial product ha ${ }^{-1}$ ) led to higher mortality rates. The shoot biomass curve revealed that doses less than 0.03 D caused biomass values to increase, and these values were similar to those recorded for the control (Figure 3). However, doses of $0.12 \mathrm{D}$ and greater had negative effects on the biomass of these plants. These data corroborate the findings of Hall (1988), who found that tomato dry biomass decreased under 2,4-D intervals from 28 to $284 \mathrm{~g}$ a.i. ha ${ }^{-1}$ as herbicide concentrations increased. Hemphill and Montgomery (1981) reported that tomato roots were the most sensitive to 2,4-D. Doses less than $2.1 \mathrm{~g}^{-1}$ caused changes in fruit shape, underscoring the deleterious effect of this herbicide on this species.

Analysis of phytotoxicity data upon treatment with dicamba (Figure 3) revealed that the effects of dicamba on tomato plants occurred rapidly. For example, $95 \%$ phytotoxicity was noted at 7 DAA. Drifts associated with $0.12 \mathrm{D}$ could be considered lethal to this species. Plants subjected to $0.03 \mathrm{D}$ exhibited increased phytotoxicity at 7 DAA; however, symptom reduction was noted in subsequent evaluations.

On the other hand, full plant recovery was not observed under this treatment. Studies based on hormone herbicide drift simulation have demonstrated that subdoses up to 0.015 of the commercial dicamba dose led to $76 \%$ phytotoxicity in tomato plants at the age of 14 days (Hemphill and Montgomery, 1981). Although the drift of $0.03 \mathrm{D}$ led to less significant biomass phytotoxicity symptoms compared with those generated by higher doses throughout the evaluations. This dose had a strong impact on plant biomass, which corresponded to accumulation resulting from the adoption of higher doses (Figure 3). Plants exposed to drift from concentrations of $0.007 \mathrm{D}$ or greater presented biomass levels similar to that recorded for the control; this outcome shows the strong suppressive effects of this herbicide on tomato plants.

Studies with other vegetable species such as broccoli and chili pepper have also demonstrated the sensitivity of these plants to very low 2,4-D and dicamba doses, which are typical of drift events. According to the authors, drift impact on plant development and total yield will likely result in 
losses to farmers (Mohseni-Moghadam and Doohan, 2015). Kruger et al. (2012) also observed the effects of glyphosate and dicamba subdoses on tomato plants. The drift of these herbicides could have strong impacts on the tomato plant yield, primarily if drift occurs at the flowering stage.

\section{Spray tank decontamination}

With respect to treatments adopted to clean the spray system, the use of spray tanks after 2,4-D application without subsequent tank washing led to the death of sensitive plants, and symptoms worsened from the $7^{\text {th }}$ to the $28^{\text {th }}$ DAA (Table 2). Although cleaning is mandatory, the number of washes influences decontamination. A high waste concentration is noted when the spray tank is washed only once. This outcome is highlighted by high phytotoxicity rates in tomato plants. However, after two washes, the spray can be used since plants in this test did not present phytotoxicity symptoms that could influence plant biomass accumulation. Such information makes the cleaning process easier because technical cleaning recommendations for the application gear after 2,4-D use include ammonia solutions (chemical solution of ammonia gas) and activated carbon (Johnson et al., 1999). These products are less common given the east of applying two to three consecutive washes with water.

Cleaning by washing with water + alcohol (1:1) was not effective, and phytotoxicity increased during the evaluations. Although biomass values under were not significantly different compared with the control, phytotoxicity symptoms (30\%) cannot be taken into account as it this method should not be applied to these herbicides.

The water + detergent method was minimally effective for cleaning tanks used to spray this herbicide. Lower results were obtained compared with those recorded for the treatment with water + alcohol (1:1). Given that detergent acts as spreader, detergent waste may have potentiate the effects of these herbicides. Costa et al. (2014) assessed the adjuvant drift effect of the 2,4-D + glyphosate mixture and found that the risk of a drift event was increased with a surfactant. Dicamba use requires washing the spray tank. Inappropriate tank washing led to high phytotoxicity results in the tested plants and eventually resulted in plant death. Water washing results with dicamba were similar to those observed for 2,4-D, i.e., two water washes were sufficient for spray tank reuse without causing phytotoxicity issues in sensitive plants. Water + alcohol (1:1) and water + detergent methods also efficiently cleaned the tank. Wash-free treatment and the treatment based on a single wash with water were the only treatments presenting biomass results different from those recorded for the control. Results from the current study emphasized the need to be diligent when spraying these herbicides in areas close to sensitive plants and to correctly clean the spray tanks before subsequent spraying on sensitive plants (Johnson et al., 2012).

\section{Materials and methods}

\section{Effects of 2,4-D and dicamba on susceptible species Plant materials}

The citrus (Citrus sinensis) variety Pêra Rio was used in this experiment. This variety has mean height of $60 \mathrm{~cm}$, and twomonth seedlings were pruned to standardized parameters and transplanted to $10-\mathrm{L}$ bags. The bags were filled with soil collected from the arable layer of Dark Red Latosol. Soil physical and chemical analyses are shown in Table 1.

We used the lettuce (Lactuca sativa) variety "Stella" (butter type). We used polypropylene trays with $162\left(31 \mathrm{~cm}^{3}\right)$ cells. After, the trays were filled with coconut fiber, three pelleted lettuce seeds were sown onto each cell and subsequently covered with expanded vermiculite. Twenty-five days after planting, the seedlings were transplanted into pots $(3.0 \mathrm{~L})$ filled with soil + commercial substrate (stabilized Pinus bark). Thirty days after transplantation, treatments were applied.

We used the tomato (Lycopersicon esculentum Mill) variety "Santa Clara" with indeterminate growth features. The same trays and substrates used for lettuce were used for tomato. Thirty days after planting, the seedlings were transplanted into pots $(3.0$ L) filled with soil + commercial substrate (stabilized Pinus bark). Treatments were applied 35 days after transplantation.

\section{Experimental design, treatments and evaluations}

Each experimental unit included a seedling of the assessed species. Independent experiments were performed for each plant species in greenhouse based on a completely randomized design with 5 repetitions. Herbicides 2,4-D (dimethylamine salt, $670 \mathrm{~g}$ a.i. $\mathrm{ha}^{-1}$ commercial dose) and dicamba (560 g a.i. ha ${ }^{-1}$ commercial dose) in seven doses were assessed in each cultivated species (citrus, lettuce and tomato). The assessed plant species were sprayed with the following doses: $0 \mathrm{D}, 1 \mathrm{D}, 0.5 \mathrm{D}, 0.12 \mathrm{D}, 0.03 \mathrm{D}, 0.007 \mathrm{D}$ and $0.001 \mathrm{D}$. Here, $D$ is the commercial dose of each herbicide. Treatments were applied using a $\mathrm{CO}_{2}$-pressurized costal sprayer under a constant pressure of $245.16 \mathrm{kPa}$. In addition, application bars were added with fen-type tips (110.03). A spray volume of $200 \mathrm{~L} \mathrm{ha}^{-1}$ was employed, and application was performed five days after plant transplantation.

Phytotoxicity evaluations were performed 7, 14, 21 and 21 days after application (DAA) using a scale based on scores where zero corresponds to injury-free plants and 100 indicates plant death (Alam, 1974). Shoot biomass was assessed at 60 and 45 DAA in citrus and vegetables, respectively. Plants were cut at the soil level; lettuce fresh mass was determined. The dry mass of tomato and citrus plants was obtained after dehydration in a forced air circulation oven at $65^{\circ} \mathrm{C}$ until constant mass was achieved.

\section{Spray tank decontamination experiments}

\section{Tomato management and evaluations}

Only tomato plants (Lycopersicon esculentum Mill var. "Santa Clara") were used as bioindicators of 2,4-D and dicamba in this experiment. The treatments were applied when 4 to 6 pairs of true leaves were observed in the plants, which occurred approximately 35 days after sowing. Phytotoxicity evaluations were performed 7, 14, 21 and 28 days after application (DAA) through a scale based on scores where zero $(0)$ corresponds to injury-free plants and 100 corresponds to plant death (Alam, 1974). Plants were cut at 45 DAA at soil level; dry biomass was determined via a forced air circulation oven at $65^{\circ} \mathrm{C}$ until constant mass was achieved.

\section{Experimental design and treatments}

The herbicide experiment was performed in a greenhouse based on a completely randomized design with five repetitions. Six spray tank cleaning methods were assessed 
Table 1. Soil chemical and physical analysis used in the experiment (2019). Dark Red Latosol

\begin{tabular}{|c|c|c|c|c|c|c|c|c|c|c|c|c|c|}
\hline $\begin{array}{l}\mathrm{P} \\
\mathrm{mg} \cdot \mathrm{dm}^{-3}\end{array}$ & $\begin{array}{l}\text { M.O } \\
\text { g.dm }\end{array}$ & $\begin{array}{l}\mathrm{pH} \\
\mathrm{CaCl}_{2}\end{array}$ & $\begin{array}{l}\mathrm{K} \\
\mathrm{Mm}\end{array}$ & $\begin{array}{l}\mathrm{Ca} \\
\mathrm{dm}^{-3}\end{array}$ & $\mathrm{Mg}$ & $\mathrm{H}+\mathrm{Al}$ & Al & $\begin{array}{l}\text { SB } \\
\%\end{array}$ & CTC & V & $\begin{array}{l}\text { Clay } \\
\text { g. } \mathrm{kg}^{-1}\end{array}$ & Sand & Silt \\
\hline 17 & 25 & 5.7 & 2.2 & 46 & 12 & 15 & 0.4 & 60.2 & 75.2 & 80 & 660 & 150 & 190 \\
\hline
\end{tabular}

Table 2. Phytotoxicity and dry biomass in young tomato plants (Lycopersicon esculentum Mill, var. Santa Clara) - results concerning methods applied to decontaminate spray tanks after 2.4-D and dicamba use (Araras, 2019).

\begin{tabular}{|c|c|c|c|c|c|}
\hline \multirow{2}{*}{ Treatments } & \multicolumn{4}{|c|}{$\%$ Phytotoxicity - 2,4D } & \multirow[b]{2}{*}{ Dry biomass (g) } \\
\hline & 7 DAA & 14 DAA & 21 DAA & 28 DAA & \\
\hline No washing & $57.50 \mathrm{ab}$ & $72.50 \mathrm{a}$ & $81.25 \mathrm{a}$ & $100.00 \mathrm{a}$ & $0.00 \mathrm{c}$ \\
\hline wash in water $1 \mathrm{x}$ & $67.50 \mathrm{a}$ & $66.25 \mathrm{a}$ & $72.50 \mathrm{a}$ & $81.25 \mathrm{a}$ & $0.33 \mathrm{bc}$ \\
\hline wash in water $2 \mathrm{x}$ & $3.75 \mathrm{~cd}$ & $3.75 \mathrm{c}$ & $5.50 \mathrm{c}$ & $10.00 \mathrm{c}$ & $2.47 \mathrm{a}$ \\
\hline wash in water $3 x$ & $2.50 \mathrm{~cd}$ & $1.25 \mathrm{c}$ & $5.00 \mathrm{c}$ & $5.00 \mathrm{c}$ & $3.15 \mathrm{a}$ \\
\hline water + alcohol 96\% & $15.00 \mathrm{~cd}$ & $17.50 \mathrm{c}$ & $22.50 \mathrm{c}$ & $30.00 \mathrm{~b}$ & $1.28 \mathrm{ab}$ \\
\hline water + detergent $(2.5 \%)$ & $32.50 \mathrm{bc}$ & $40.00 \mathrm{~b}$ & $47.50 \mathrm{~b}$ & $70.00 \mathrm{a}$ & $0.71 \mathrm{~b}$ \\
\hline Control (no herbicide) & $0.00 \mathrm{~d}$ & $0.00 \mathrm{c}$ & $0.00 \mathrm{c}$ & $0.00 \mathrm{c}$ & $3.75 \mathrm{a}$ \\
\hline VC (\%) & 54.45 & 33.55 & 30.29 & 26.95 & 64.60 \\
\hline \multirow{2}{*}{ Treatments } & \multicolumn{4}{|c|}{ \% Phytotoxicity - Dicamba } & \\
\hline & 7 DAA & 14 DAA & 21 DAA & 28 DAA & Dry biomass (g) \\
\hline No washing & $76.25 \mathrm{a}$ & $87.50 \mathrm{a}$ & $96.25 \mathrm{a}$ & $100.00 \mathrm{a}$ & $0.00 \mathrm{~b}$ \\
\hline wash in water $1 \mathrm{x}$ & $77.50 \mathrm{a}$ & $77.50 \mathrm{a}$ & $77.50 \mathrm{a}$ & $71.25 \mathrm{~b}$ & $0.84 \mathrm{~b}$ \\
\hline wash in water $2 \mathrm{x}$ & $7.50 \mathrm{~b}$ & $5.00 \mathrm{~b}$ & $3.75 \mathrm{~b}$ & $0.00 \mathrm{c}$ & $3.81 \mathrm{a}$ \\
\hline wash in water $3 x$ & $12.50 \mathrm{~b}$ & $7.50 \mathrm{~b}$ & $5.00 \mathrm{~b}$ & $0.00 \mathrm{c}$ & $3.46 \mathrm{a}$ \\
\hline water + alcohol $96 \%$ & $17.50 \mathrm{~b}$ & $20.00 \mathrm{~b}$ & $15.00 \mathrm{~b}$ & $10.50 \mathrm{c}$ & $3.00 \mathrm{a}$ \\
\hline water + detergent $(2.5 \%)$ & $12.50 \mathrm{~b}$ & $17.50 \mathrm{~b}$ & $17.50 \mathrm{~b}$ & $15.00 \mathrm{bc}$ & $3.00 \mathrm{a}$ \\
\hline Control (no herbicide) & $0.00 \mathrm{~b}$ & $0.00 \mathrm{~b}$ & $0.00 \mathrm{~b}$ & $0.00 \mathrm{c}$ & $3.75 \mathrm{a}$ \\
\hline VC (\%) & 18.54 & 21.33 & 29.08 & 13.87 & 50.04 \\
\hline
\end{tabular}

Means followed by the same letter in the column did not significantly differ from each other in the Tukey test at $5 \%$ probability.

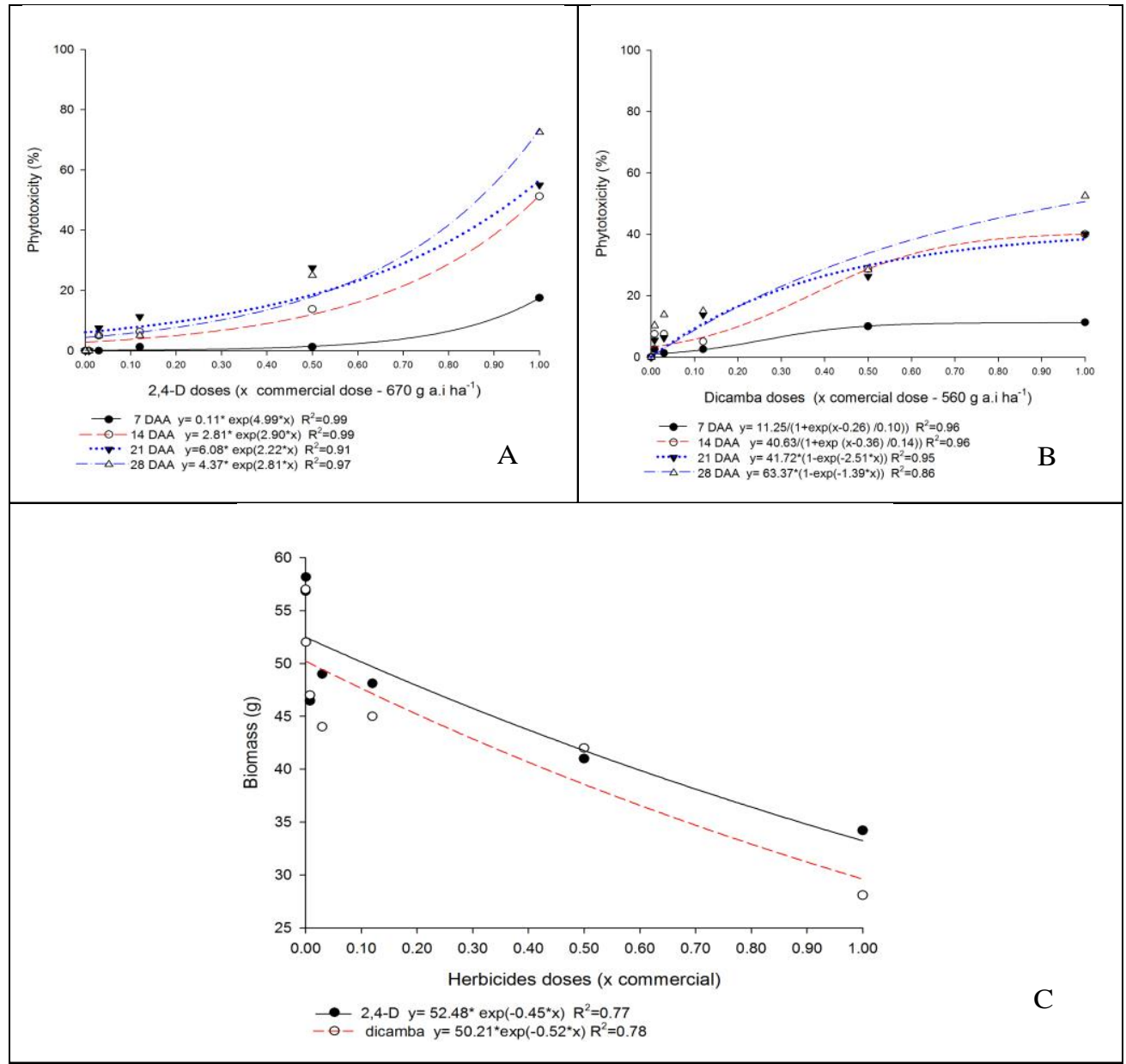

Fig 1. Phytotoxicity of 2.4-D (A) and dicamba (B) doses applied on citrus plants (Citrus sinensis var. Pêra Rio) assessed at 7, 14, 21 and 28 DAA and their effect on biomass (C) (Araras, 2019). 


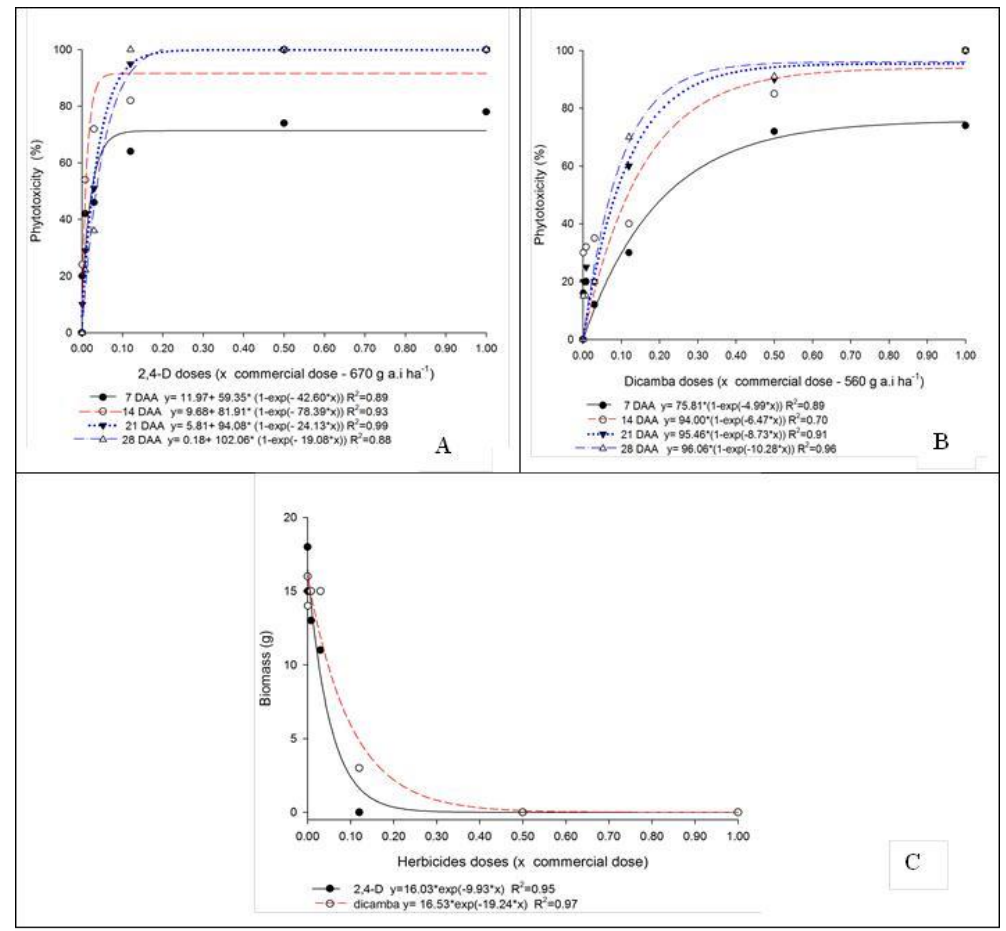

Fig. 2 Phytotoxicity of 2.4-D (A) and dicamba (B) doses applied on young lettuce plants (Lactuca sativa var. Stella) assessed at 7, 14, 21 and 28 DAA and their effect on biomass (C) (Araras, 2019).

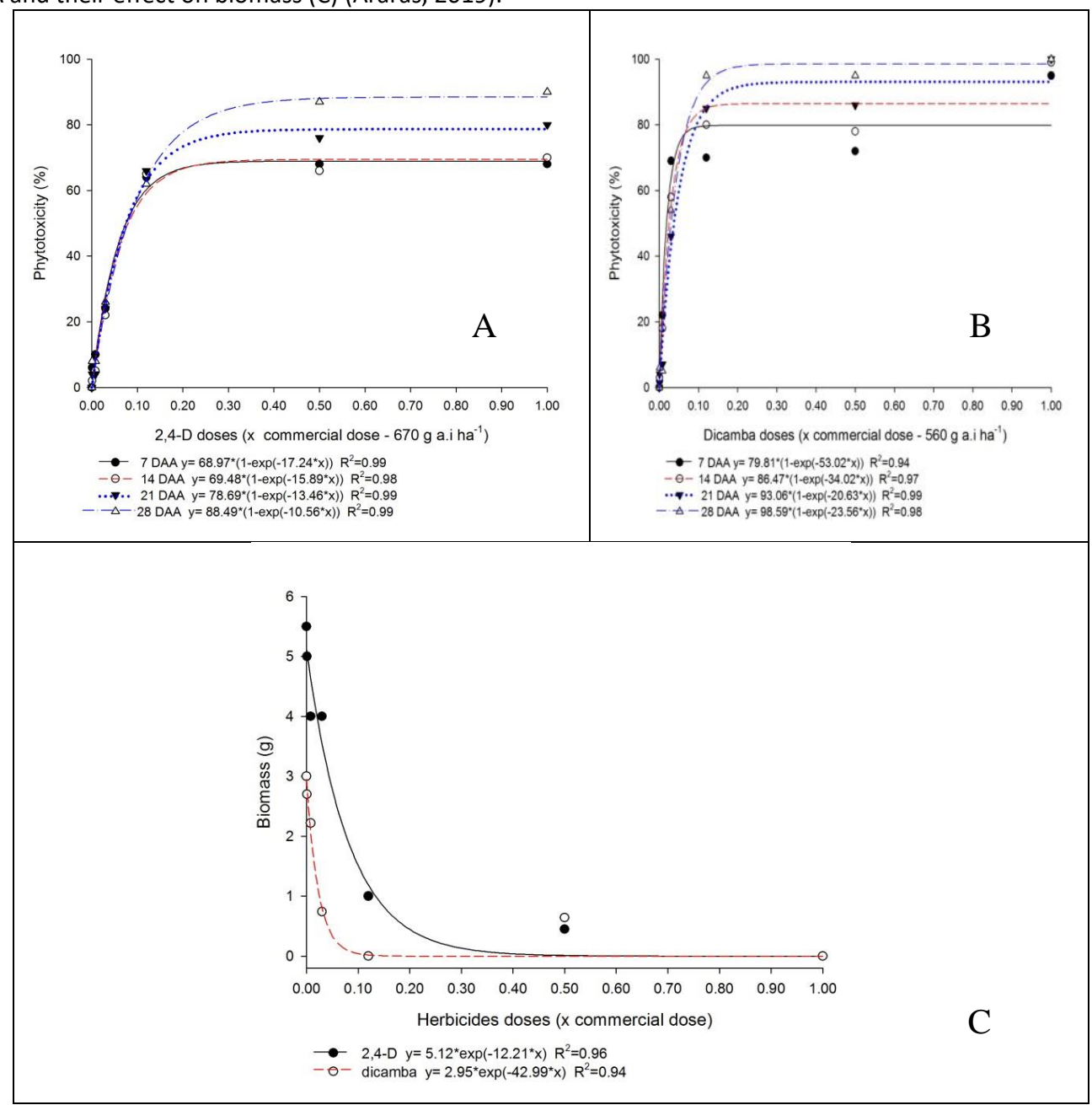

Fig. 3. Phytotoxicity of 2.4-D (A) and dicamba (B) sub-doses applied on young tomato plants (Lycopersicon esculentum Mill, var. Santa Clara) - assessed at 7, 14, 21 and 28 DAA and their effect on biomass (C) (Araras, 2019). 
after these tanks were used to apply auxin mimics 2,4-D and dicamba herbicides.

The spray tank used in this study is a polyethylene tank $(20 \mathrm{~L}$ volume). Two spray devices were used to apply each herbicide. Briefly, 2,4-D herbicide was applied at a dose of $670 \mathrm{~g}$ a.i. ha ${ }^{-1}$ and the dicamba dose was $560 \mathrm{~g}^{\text {a.i. }} \mathrm{ha}^{-1}$. Separate tanks were used for each spray. The doses were applied on carrier areas to control eudicotyledonous weeds until the total volume in the tank was used. Sprayings were performed under adequate temperature $\left(24^{\circ} \mathrm{C}\right)$ and wind speed $\left(2.0 \mathrm{~m} \mathrm{~s}^{-1}\right)$ conditions.

The tanks were subjected to different cleaning methods after application: 1 ) wash with water $1 \mathrm{x}$ (one time); 2 ) water $2 x$ (two times); 3) water $3 x$ (three times); 4) in water + alcohol $96 \%$ (1:1) one time; 5) water + detergent degreaser suitable for agricultural use (2.5\%) one time and; 6) no washing. After the cleaning process, the tank was filled with water and used to spray the herbicide on tomato seedlings.

\section{Statistical analyses}

The collected data were subjected to analysis of variance. The means of significant qualitative data were compared using Tukey's test at 5\% probability. Quantitative data were analyzed using nonlinear regressions with the statistical program SigmaPlot (version 10.0) from Systat Software, Inc. (San Jose, California, USA).

\section{Conclusions}

Citrus (Citrus sinensis) plants present low loss potential from 2,4-D and dicamba drift at the beginning of their development. A dose of $0.12 \mathrm{D}$ of both herbicides was tolerated by the plants. Lettuce (Lactuca sativa) tolerated 2,4-D at a dose of $0.007 \mathrm{D}$; despite the appearance of phytotoxicity symptoms, the tolerated dicamba dose was $0.03 \mathrm{D}$. The drift from only $0.03 \mathrm{D}$ 2,4-D was acceptable for tomato (Lycopersicum esculentum); despite the appearance of phytotoxicity symptoms, the tolerated dicamba dose was $0.007 \mathrm{D}$.

Washing the spray tank with water (at least twice) was the most appropriate cleaning method after 2,4-D was used. Washing with water twice, water + alcohol (1:1) or water + detergent exhibited equal cleaning efficacy after spraying with dicamba.

\section{Acknowledgments}

The authors thank CNPq for financial support, the Agronomic Institute of Campinas (IAC) for the citrus plants and BASF for the dicamba herbicide.

\section{References}

Adouli B, Zamani Z, Fattahi-Mohgadam MR, Golein B, Rezaei $K$ (2018) Effects of alternate bearing and 2,4-D application on fruit growth pattern, abscission enzymes activity, ACC content of calyx and carbohydrates partitioning of fruits in Satsuma mandarin (Citrus unshiu Marc.) cv. Miyagawa. Scientia Horticulturae. 238: 58-65.

Almeida IML, Rodrigues JD, Ono EO (2002) Aplicação de reguladores vegetais no retardamento da abscisão de frutos de laranjeira -'Hamlin'1. Rev. Bras. Frutic. 24:306311.

Asociación Latinoamericana de Malezas, ALAM (1974) Recomendaciones sobre unificacion de los sistemas de evaluacion en ensayos de control de malezas. ALAM. 1: 3538.

Behrens MR, Mutlu N, Chakraborty S, Dumitru R, Jiang WZ, La Valle BJ, Herman PL, Clemente TE, Weeks DP (2007) Dicamba resistance: enlarging and preserving biotechnology-based weed management strategies. Science. 316: 1185-1188.

Breeze VG, West CJ (1987) Long- and short-term effects of vapour of the herbicide 2,4-D butyl on the growth of tomato plants. Weed Research. 27: 13-21.

Cobb A, Reade JPH (1992) Auxin-Type Herbicides. In: Reade JPH (ed) Herbicide and plant physiology. Chapman e Hall, London.

Companhia Nacional de Abastecimento, CONAB (2017) Acompanhamento da safra brasileireira de grãos: $11^{\circ}$ Levantamento da safra de grãos.

Comissão Técnica Nacional de Biossegurança, CTNBio (2016) 198a Reunião Ordinária da Comissão Técnica Nacional de Biossegurança-CTNBio.

Costa AGF, Velini ED, Rossi CVS, Corrêa MR, Negrisoli E, Fiorini MV, Siolo LM (2014) Adjuvantes na deriva de 2,4-D + glyphosate em condições de campo. Ciência Rural. 44: 387-392.

Derksen DA (1989) Dicamba, chlorsulfuron, and clopyralid as sprayer contaminants on sunflower (Helianthus annuus), mustard (Brassica juncea), and lentil (Lens culinaris), respectively. Weed Science. 37: 616-621.

Everitt JD, Keeling JW (2009) Cotton Growth and Yield Response to Simulated 2,4D and Dicamba Drift. Weed Tech. 23: 503-506.

Gaspar N, Maso L, Ribeiro NM, Silva PV, Silva PV, Santos PHV, Monquero PA (2017) Efeitos fitotóxicos sobre a cultura do alface ocasionados pela deriva de herbicidas utilizados no milho. Ensaio Pioneiros. 1: 1-13.

Grossmann K (2000) Induction of abscisic acid is a common effect of auxin herbicides in susceptible plants. Journal of Plant Physiology. 149: 475-478.

Hall JC, Swanton CJ (1988) Selectivity of 2,4-D in Solanum ptycanthum Dun. and Lycopersicon esculentum Mill. Weed Research. 28: 117-126.

Hemphill Jr DD, Montgomery ML (1981) Response of vegetable crops to sublethal application of 2,4-D. Weed Science. 29: 632-635.

Howard PH (ed) (1989) Handbook of Environmental Fate and Exposure Data for Organic Chemicals Vol. III: Pesticides. Lewis Publishers, Chelsea, MI.

Johnson B, Casady B, Peterson D, Kuhlman D (1999) Cleaning field sprayers to avoid crop injury. Weed Control. 10: 1-6.

Johnson VA, Fisher LR, Jordan DL, Edmisten KE, Stewart AM, York AC (2012) Cotton, Peanut, and Soybean Response to Sublethal Rates of Dicamba, Glufosinate, and 2,4-D. Weed Tech. 26: 195-206.

Jones GT, Norsworthy JK, Barber T (2019) Off-target movement of diglycolamine dicamba to non-dicamba soybean using practices to minimize primary drift. Weed Tech. 33: 24-40.

Kruger GR, Johson WG, Doohan DJ, Weller SC (2012) Dose Response of Glyphosate and Dicamba on Tomato (Lycopersicon esculentum). Weed Tech. 26: 256-260. 
Marple ME, Al-Khatib K, Shoup D, Peterson DE (2007) Cotton response to simulated drift of seven hormonal-type herbicides. Weed Tech. 27: 987-992.

Marple ME, Al-Khatib K, Peterson DE (2008) Cotton Injury and Yield as Affected by Simulated Drift of 2,4-D and Dicamba. Weed Tech. 22: 609-614.

Miller PCH (1993) Spray drift and its measurement. In: Matthews GA, Hislop EC Application technology for crop protection, CAB International.

Mohseni-Moghadam M., Wolfe S, Dami I, Doohan D (2016) Response of wine grape cultivars to simulated drift rates of 2,4-D, dicamba, and glyphosate. Weed Techn. 30:807-814.

Mohseni-Moghadam M, Doohan D (2015) Response of bell pepper and broccoli to simulated drift rates of 2,4-D and dicamba. Weed Tech. 29:226-232.

Moro MS, Yamauti MS, Nepomuceno M, Alves PLCA (2012) Deriva simulada de herbicidas utilizados em cana-deaçúcar em alface (Lactuca sativa). Paper presented the XXVIII Congresso Brasileiro da Ciência das Plantas Daninhas, Campo Grande - MS, 3-6 september 2012.

Mueller T (2015) Methods to measure herbicida volatility. Weed Science. 63: 116-120.

Nascimento ALV, Reis MR, Aquino LA, Ruas RAA (2018) Deriva de herbicidas auxínicos (2,4-D e Dicamba) em olerícolas. In: Boletim Técnico da Universidade para o Agricultor, Viçosa, UFV.

Ramos HH, Durigan JC (1996) Avaliação da eficiência da mistura pronta de glyphosate $+2,4-D$ no controle da Commelina virginica L. em citros. Planta Daninha. 14: 33 41.

Santos DP, Braga RR, Guimarães FAP, Passos ABRJ, Silva DV, Santos JB, Nery MC (2013) Determinação de espécies bioindicadoras de resíduos de herbicidas auxínicos. Revista Ceres. 60: 354-362.

Spaunhorst D, Siefert-Higgins S, Bradley KW (2014) Glyphosate-resistant giant ragweed (Ambrosia trifida) and waterhemp (Amaranthus rudis) management in dicamba resistant soybean (Glycine max). Weed Tech. 28:131-141.

Wells, ML, Prostko, EP, Carter, W (2019) Simulated single drift events of 2,4-d and dicamba on pecan trees. Hort Technology. 29:360-366.

Werle R, Oliveira M, Jhala A, Proctor C, Rees J, Klein R (2018). Weed Tech. 32: 754-761.

Weidenhamer JD, Triplett Jr GB, Sobotka FE (1989) Dicamba injury to soybean. Agronomy Journal. 81: 637-643. 